\title{
Dissecting Bioethics
}

"Dissecting Bioethics," edited by Tuija Takala and Matti Häyry, welcomes contributions on the conceptual and theoretical dimensions of bioethics.

The section is dedicated to the idea that words defined by bioethicists and others should not be allowed to imprison people's actual concerns, emotions, and thoughts. Papers that expose the many meanings of a concept, describe the different readings of a moral doctrine, or provide an alternative angle to seemingly selfevident issues are therefore particularly appreciated.

The themes covered in the section so far include dignity, naturalness, public interest, community, disability, autonomy, parity of reasoning, symbolic appeals, and toleration.

All submitted papers are peer reviewed. To submit a paper or to discuss a suitable topic, contact Tuija Takala at tuija.takala@helsinki.fi.

\section{Dignity: Two Riddles and Four Concepts}

\section{DORIS SCHROEDER}

\section{Two Dignity Riddles}

I M A G I N E a dignified death ... your own. Where are you? Who is with you? Do you fall asleep without waking up? If you live in a Western, industrialized society, your thoughts may quickly turn to a particular type of death. For instance, the vision of yourself lying in bed with a debilitating illness, unable to eat by yourself, unable to wash yourself or go to the bathroom, incontinent or connected to urinary tubes, tended by strangers in a hospital, potentially demented, puzzled, lonely, unable to comprehend where you are and in serious pain.

Observations of lonely, painful, institutionalized dying and the fear thereof have sparked Death with Dig-

I would like to thank research seminar members at the Centre for Applied Philosophy and Public Ethics at the University of Melbourne, Australia, Armin Schmidt, Julie Lucas, and Tuija Takala for their helpful comments. nity movements around the world, ${ }^{1}$ organizations created to show "courage and compassion in an area of deep concern to us all-the making of wise and deliberate choices at the end of life," 2 in other words, the choice to die from one's own or a physician's hand. For many, death with dignity means dying without excruciating pain, without relatives having to witness the aching disintegration of their loved ones, and without the embarrassment of needing help for the most basic human functions. To achieve their aims of legalizing physician-assisted suicide or euthanasia, Death with Dignity organizations appeal almost exclusively to the concept of dignity, as the names of organizations throughout the world testify. ${ }^{3}$ But, surprisingly, so do their opponents, as the following three quotes show:

[T]o kill an innocent human life, whether one's own or another's, even 
for the sake of avoiding terrible suffering, is intrinsically immoral. Euthanasia and suicide are contrary to the intrinsic dignity of human persons. ${ }^{4}$

This sense of the ... dignity of all human life has been influential in maintaining traditional western prohibitions against abortion, suicide, euthanasia, and hazardous medical experimentation on human subjects. ${ }^{5}$

We want our deaths to be free from pain, mess, embarrassment. But there is a long Christian tradition of "holy death," that is, of allowing even a hard death to be a witness to God's grace. We're nowhere invited to ring down the curtain early to preserve our pride. How dignified did Jesus look on the way to the cross? Spattered with blood and spit, despised and rejected, he carried his own instrument of torture up a hill. Was this a death with dignity? Ironically, it was. ${ }^{6}$

Dignity forbids suicide or euthanasia according to the above three authors, whereas it demands suicide or euthanasia according to Death with Dignity organizations. This is our first dignity riddle. Two opposing groups ${ }^{7}$ discussing the same topic both using the concept of dignity to support their positions! How can this be possible?

I M A G I N E a dignified person.... Whom do you see? Perhaps Nelson Mandela, who kept his poise and self-respect during 26 years of imprisonment? Or Nobel Peace Laureate Aung San Suu Kyi, who spent 11 of the past 18 years in some form of detention in Burma without losing her serenity? Or Antigone, daughter of Oedipus, who combined heroic courage with gentle care for her father and brother? Whatever you see, it is unlikely to be a mass murderer, a torturer, a rapist, or a pedophile. In general, one associates dignity with certain character dispositions that prevent evil behavior. For instance, rational self-control, composure, calmness, but also the power of self-assertion and belief in one's own worth. Dignity is a quality that generates respect and even awe among those who observe it. ${ }^{8}$ Yet, if dignity is restricted to persons who generate awe in observers, how can one explain its appearance in numerous national constitutions and many ethical guidelines? "Human dignity is inviolable" starts the German constitution, and the Universal Declaration of Human Rights bases freedom, justice, and peace on "the recognition of the inherent dignity ... of all members of the human family."

If all human beings have inherent dignity, the same would apply to torturers and rapists, and there is no difference-in this respect-between Mother Theresa and Adolf Hitler. So why, when asked to imagine persons with dignity, do we name specific people for whom we feel awe? Why do we only think of some people when asked about dignity? Doesn't this imply that one can either lose or never possess it? This is our second dignity riddle.

\section{Is Dignity a Useless Concept?}

Ruth Macklin contended that "dignity is a useless concept." ${ }^{9}$ Franz Josef Wetz agreed and expressed more flourishingly that "dignity is an entry from the old-European grand vocabulary, which not unlike drugs tricks the addict into believing in fantastic fake solutions for deep conflicts." ${ }^{10}$ Helga Kuhse argued that "the notion of human dignity plays a very dubious role in contemporary bioethical discourse.... [It] has a tendency to stifle argument and debate and encourages the drawing of moral boundaries in the wrong places." ${ }^{11}$ Macklin's, Wetz's, and Kuhse's modern voices echo older 
warnings by Arthur Schopenhauer (1788-1860), for whom dignity was going to develop into the shibboleth ${ }^{12}$ of all thoughtless philosophers, a word for an idea that cannot be thought, such as the highest number or the largest space. ${ }^{13}$

The above authors suggest that dignity is to be purged from ethical discourse. And, indeed, if the concept is so vague that it can be used to defend opposing positions, so it should. However, all four address their concerns to the Kantian concept only, without distinguishing it from others. By introducing four different concepts and by shedding light on the two posed dignity riddles, I intend to show that there is hope for dignity yet. As Matti Häyry put it, if nobody monopolizes the term, the recognition that dignity is multifaceted can lead to constructive dialogue between people and cultures. ${ }^{14}$

\section{Four Concepts of Dignity}

\section{Kantian Dignity}

The most prominent Western understanding of dignity goes back to Immanuel Kant (1724-1804), who believed he could prove the existence of a supreme law of morality ${ }^{15}$ and its link to human dignity. Due to the complexity of his thought, Kant is one of the most difficult philosophers to abridge. Still, in order to understand Kantian dignity, the main elements of his ethical theory need to be outlined very briefly. Kant started his explorations into ethics from moral common sense, which he saw captured in the following sentence:

It is impossible to think of anything at all in the world, or indeed even beyond it, that could be considered good without limitation except a good will. ${ }^{16}$

Based on this observation, Kant infers that morality is intimately linked with duty. How does he make this inference? For Kant, God is the only being who can only act morally. Animals, on the other hand, cannot act morally at all. Human beings belong to neither category as they can act morally and immorally. Based on his premise that only a good will is intrinsically good, Kant states that the concept of "duty" is included in the concept of the "good will." The good will needs to be directed at something and this can only be the moral good. It would not be a good will if it were directed at anything else. Hence, to distinguish oneself from animals one has to strive for the moral good, that is, one has a duty to be moral.

The ability to separate good and bad depends on the human faculty of reason. Only because human beings are rational is it possible for them to decide between morally right and wrong. And now comes Kant's move to human dignity! Every individual rational being is an end in itself, somebody with life plans. Such a being should not be bought by others like commercial goods and used for their own purposes. Human beings have intrinsic worth, not a price for which they can be acquired. ${ }^{17}$ They have absolute inner worth (absoluten innern Wert $\left.{ }^{18}\right)$. Or as Kant scholars often put it, human beings have dignity because of their "rational nature in its capacity to be morally self-legislative." 19

The term that has been coined for this type of dignity is gift or dowry dignity, ${ }^{20}$ dignity one has intrinsically, without ever being able to lose it. ${ }^{21}$ Kant alludes to this point when he says, "I cannot deny all respect even to a vicious man." ${ }^{22}$ What does it mean if somebody has dignity in the Kantian sense? According to Kant, a person with dignity has rights, "an absolute inner worth by which he extorts (abnötigen) respect for himself from all other rational be- 
ings in the world." 23 Thus right holders must not be instrumentalized by other human beings without their reasonable consent or, in Kant's own words,

act in such a way that you always treat humanity, whether in your own person or in the person of any other, never simply as a means, but always at the same time as an end. ${ }^{24}$

This statement of Kant's is also known as the Formula of Humanity. $^{25}$ Based on the above, Kantian dignity could be defined as follows: "Dignity is a property of all rational beings, ${ }^{26}$ which gives the possessor the right never to be treated simply as a means, but always at the same time as an end." However, international laws and national constitutions have stressed the inviolability of human dignity and expanded its scope to include all human beings. The modern Kantian-inspired definition of dignity would therefore be

Dignity is an inviolable property of all human beings, which gives the possessor the right never to be treated simply as a means, but always at the same time as an end.

\section{Aristocratic Dignity}

The Latin term dignitas links directly to ornament, distinction, or glory. ${ }^{27}$ When one talked about dignity in premodern times, one referred to stratified societies where some people were valued higher than others. The German word Würdenträger [carrier of dignity] is a clear indication of such traditions. Carriers of dignity were invested with secular or religious positions of high rank, and they behaved in a dignified way when they acted in accordance with this position. Often it was assumed that God invested carriers of dignity with their rank or that it was handed down through noble families. Kings, popes, or other nobles would be regarded as dignified if their conduct befitted those of higher rank. ${ }^{28}$ Thus, dignity was restricted to an infinitesimally small number of human beings and strongly associated with a position. A suitable term for this type of dignity would be aristocratic dignity. ${ }^{29}$ And one could define it as follows:

Dignity is the outwardly displayed quality of a human being who acts in accordance with her superior rank and position.

\section{Comportment Dignity}

Aristocratic dignity links dignity to outward displays of actions. If somebody wears a heavy silk gown, carries a sceptre, and walks in front of a large number of state officials with an upright posture at slow pace, we can assume that he has a position of superior rank. Yet, by describing a king who walks in front of his members of court, I just combined two elements of dignity, which can be separated: the dignity when acting in accordance with superior rank and position and the dignity of appropriate and seemly comportment. Let us look at two literature quotes to illustrate the point.

Her gloves were not merely wellworn but battered, Rasumichin noticed, and yet this evident poverty gave the ladies an air of dignity, which can be found in people who know how to wear shabby clothes. Razumihin looked reverently at Dunetschka ...." "The queen who mended her stockings in prison," he thought quietly, "must have looked like a queen and even more royal than at sumptuous banquets and receptions!" (Fjodor Dostojewski, Crime and Punishment, ${ }^{30}$ emphasis added)

The two ladies Dostojewski describes cannot claim superior rank or 
position; otherwise they would not be so poor. Dostojewski wrote Crime and Punishment five decades before the rule of the Tsars ended. Under this regime, those of noble birth or in superior state positions would not have worn battered gloves. Yet, Dostojewski compares one of the ladies with a queen in prison, somebody who has queenly comportment despite being forced by circumstances beyond her control to mend her own stockings. This example gives us the outward display of aristocratic dignity, namely noble comportment, but in two ladies who contemporaries in Russia would have called of inferior social rank.

Certain outward signs of dignified behavior are expected in most societies from most human beings. Let us look at a second literature quote.

He had not slept a wink. ... His lips curled in an involuntary sneer as he looked around the train carriage and saw how many of the passengers were already ... either dozing, or napping, or nodding off, or snoozing, or snatching forty winks, their mouths hanging stupidly open, their heads lolling, their eyelids drooping heavily. Did these people have no sense of dignity, no self-respect? (Jonathan Coe: The House of Sleep, ${ }^{31}$ emphasis added)

Societies have myriad rules about dignified comportment, and the protagonist in Coe's novel strongly believes that sleeping in public with one's mouth open and head lolling violates one of them. In the same way as Coe's protagonist believes it is undignified to snooze on a train, it could appear undignified to tell a rude joke at an official dinner with one's mouth full, to giggle at an obituary, to kiss one's partner in a Catholic church (unless he is the groom), to spit onto the street, to undress or relieve oneself in public, and so forth. This type of dignity, which we could name comportment dignity, can be defined as follows:

Dignity is the outwardly displayed quality of a human being who acts in accordance with society's expectations of well-mannered demeanor and bearing.

\section{Meritorious Dignity}

Aristotle did not mention dignity in the Nichomachean Ethics. Yet two attributions ${ }^{32}$ to Aristotle are often quoted.

- Dignity does not consist in possessing honors, but in deserving them.

- The ideal man bears the accidents of life with dignity ... making the best of circumstances.

In the first quote, Aristotle contrasts two perceptions of possible dignity. First, one is dignified if one possesses honors. Second, one is dignified if one deserves to possess those honors. The quote indicates that one can appear to have dignity (if one possesses honors) without deserving it. The mere appearance of dignity through the possessions of honors is reminiscent of the aristocratic view on dignity. As noted previously, the Latin term dignitas links directly to ornament, distinction, or glory. Ornament in particular refers to something that can be displayed without the equivalent merit or desert. This is not dignity for Aristotle. Dignity consists in deserving not displaying honors, in other words, being honorable. Honorable is, of course, another word for being morally praiseworthy, principled, respectable, upright, admirable as my thesaurus assures me. Hence, dignity is linked to the cardinal virtues for Aristotle. To be morally praiseworthy, principled, and admirable means to have a reliable character disposition toward courage, justice, wis- 
dom, and temperance, given Aristotle's belief in the unity of the virtues. ${ }^{33}$

Does the second quote point us in a similar direction? "The ideal man bears the accidents of life with dignity ... making the best of circumstances." What the ideal man (or woman) is bearing are not happy accidents of life, but those involving pain and suffering; otherwise they would not have to be borne. This quote therefore points toward a quality that human beings need when their life is difficult, when circumstances cause anguish, distress, and hurt rather than joy and warmth and peacefulness. Which qualities would you wish your friends had when they suddenly encountered a serious misfortune? Would these not be the cardinal virtues as well as a sense of self-worth? It most definitely cannot be outer ornaments and honors; neither can it be intrinsic worth that everybody possesses, because Aristotle spoke of the "ideal" man and not of "every" man. To cope with life's accidents, one needs inner strength, not outer recognition. For instance, a friend of my parents just died in a hospital very suddenly and unexpectedly at the age of 60. In Germany, with a female life expectancy of 82 , this is regarded as too young to die, and it is therefore considered a serious misfortune. What would I wish the grieving husband? I would wish that he can bear this misfortune with courage, the courage necessary to get through serious pain and suffering. I would wish that he has temperance and patience and does not make it his life's purpose to try to find desperately somebody whom he could blame. I would also wish that he has the wisdom to see that all life ends and that this end is beyond our control. I would wish him a sense of self-worth, so that he does not think his life ends with his wife's. And I would wish him a sense of justice in his dealings with children and grandchildren. They deserve his support. All the cardinal virtues as well as a sense of self-worth are required to bear the accidents of life, and Aristotle uses one word to cover them, namely dignity. One could arguably contend that dignity is a virtue (a reliable character disposition ${ }^{34}$ ). In fact, it is not an individual virtue, but a keynote to the cardinal virtues. Those who possess temperance, courage, and justice and are guided by wisdom display dignity in its most perfect instantiation. ${ }^{35}$

Based on these considerations, meritorious dignity could be defined as follows:

Dignity is a virtue, which subsumes the four cardinal virtues and one's sense of self-worth.

\section{Dignity Riddles Tackled}

Let us return to the first dignity riddle (defending opposing views on physicianassisted suicide with the same concept). Death with Dignity organizations advocate the option of an accelerated death for competent adults who are "suffering unbearably from incurable illness." 36 Acceleration of death aims at mercifully releasing a person from having to go through the final stages of a terminal illness. A death with dignity is equated with a death in peace and without suffering. ${ }^{37}$ If one sees peace as a state of harmony, the following three scenarios $^{38}$ seem to militate most strongly against a peaceful death in the healthcare setting. ${ }^{39}$ In 2002, Diane Pretty died in the United Kingdom from motor neuron disease. She had unsuccessfully campaigned for her right to assisted suicide, as she feared the choking and asphyxia in the final stage of her disease. According to her husband, "Diane had to go through the one thing she had foreseen 
and was most afraid of-and there was nothing I could do to help." ${ }^{40}$ In 1995, a prison inmate in Washington, D.C., was left in soiled bedding for 10 days, unable to walk to the lavatory, incontinent, and dying from AIDS. Because of the stench in his cell, no medical staff would treat him. He finally died tied to a wheelchair with a urine-stained sheet. ${ }^{41}$ Peter Allmark recalls a terminal lung cancer patient who was frequently in such severe pain that he screamed in his U.K. hospital where pain control was badly managed and morphine only given in inadequate amounts and at low frequencies. ${ }^{42}$ According to these three examples, extreme anxiety, deep embarrassment, and unbearable pain militate against a peaceful death in the medical setting. And it is those scenarios that lead to fears about loss of dignity. ${ }^{43}$

A group of eminent philosophers (Dworkin, Nagel, Nozick, Rawls, Scanlon, and Jarvis Thomson) joined Death with Dignity organizations in their advocacy work and published the following plea in the New York Times Book Review: "Most of us see death ... as the final act of life's drama, and we want that last act to reflect our own convictions, those we have tried to live by, not the convictions of others forced on us in our most vulnerable moment." 44

Equipped with our four definitions of dignity, we can say about the first riddle that unbearable pain, embarrassment, and anxiety have no relevance for Kantian-inspired, inviolable dignity. Such intrinsic dignity cannot be lost and is not available in degrees. Those under extreme pain, embarrassment, and anxiety have no less or no more dignity than the more fortunate. This is why the Christian authors cited above use the concept of dignity to oppose physicianassisted suicide. The purposeful accel- eration of death of an intrinsically valuable being is contrary to this being's intrinsic dignity and must therefore be prevented. By contrast, Death with Dignity organizations and the above philosophers seem to align dignity with effort and values that one has lived by in the past. They, therefore, appeal to the meritorious and the comportment concept of dignity. What one might have tried all one's life, to fit into society's standards of decent behavior, one might not be able to achieve in death. And to have this witnessed by others on whom one is dependent leads to one's perception of lost comportment dignity. At the same time, unbearable pain and extreme anxiety may undermine the cardinal virtue of wisdom and thereby the associated cardinal virtues of courage, justice, and temperance. Even though the most virtuous may achieve dignity in death despite substantial torments (one of the Christian authors above cites Jesus' death as an example), Death with Dignity organizations implicitly maintain that nobody should have to. If one does not want to die from foreseeable asphyxia in the final stages of a terminal disease, one's meritorious dignity should not be thus tested. Those groups who contributed to our first riddle therefore use highly different concepts when they appeal to dignity and specification of concepts is important in resolving the riddle.

Of course, advocates of physicianassisted suicide such as the above cited philosophers focus mostly on the respect of autonomy in dying patients. However, if dignity and respect for autonomy were equated, Ruth Macklin would be right. Dignity would be superfluous and could be eliminated from bioethical discourse. However, I hope to have shown in the above short discussion that dignity is more than respect for autonomy and that an analysis of dignity concepts has the poten- 
tial to illuminate debates as long as one does not expect dignity to have only one, clearly delineated meaning.

In the same way as light can be shed on the first dignity riddle by taking the different meanings of dignity into account, so can the second dignity riddle be moved toward resolution. People like Nelson Mandela and Aung San Suu Kyi show dignified defiance in their fight for human rights. Dignified defiance is mostly fueled by dignity as a virtue, a strong sense of self-worth, courage, wisdom, temperance, and justice. Yet, it also has an element of comportment dignity, as shown in defiant posture and poise. When asked who shows great dignity, human beings tend to look for dignity as a virtue with the required comportment and not as an intrinsic quality of human beings, which can never be lost (the view expressed by most legislative instruments).

I would not maintain that dignity has necessarily been delineated exhaustively in my four different definitions. Neither would I argue that deepseated moral dilemmas can easily be resolved by an appeal to any particular notion of dignity. However, as Derek Beyleveld and Roger Brownsword ${ }^{45}$ have rightly noted, dignity is a slippery idea, but it is also a very powerful one and the demand to purge it from ethical discourse amounts to whistling in the wind. It is better to try and eliminate some of its slipperiness than to ignore its supremacy in everyday morality $^{46}$ and national and international law.

\section{Notes}

1. For an umbrella organization, see the World Federation of Right to Die Societies at: http:// www.worldrtd.net/ (accessed Jul 14, 2007).

2. Resources. Death with Dignity National Center at: http://www.deathwithdignity.org/ resources (accessed Aug 22, 2007).
3. The World Federation of Right to Die Societies-Our Members, at: http://www. worldrtd.net/members (accessed Aug 22, 2007).

4. Patrick L. Personhood, dignity, suicide and euthanasia. The National Catholic Bioethics Quarterly 2001:1(3), reprinted at http://www. lifeissues.net/writers/leep/leep_01dignity1. html (accessed July 15, 2007).

5. Vautier BH. Definitions of death. Dignity and Dying: A Christian Appraisal. Grand Rapids: Eerdmans; 1996:96-104, reprinted at: http:// www.theologymatters.com/TMIssues/May jun97.pdf (accessed Jul 15, 2007).

6. Mathewes-Green F. Dignity, always dignity. World Magazine Feb 18, 1995, reprinted at: http://www.theologymatters.com/TMIssues/ Mayjun97.pdf (accessed Jul 15, 2007).

7. A third position will not be outlined here due to lack of space. According to Christopher Coope, "death with dignity" is an unsatisfactory and unclear phrase, which should simply be given up. Coope CM. Death with dignity. Hastings Center Report 1997;27(5):37-8.

8. Kolnai A. Dignity. Philosophy 1976;5(1)25171 at p. 252.

9. Macklin R. Dignity is a useless concept. British Medical Journal 2003;327:1419-20.

10. Translated from German and paraphrased. Wetz FJ. Menschenwürde als Opium fürs Volk. Der Wertstatus von Embryonen. In: Kettner M, ed. Biomedizin und Menschenwürde. Frankfurt: Edition Suhrkamp; 2004: 221-48.

11. Kuhse H. Is there a tension between autonomy and dignity? In: Kemp P, Rendtorff J, Mattson Johansen N, eds. Bioethics and Biolaw, Vol. II: Four Ethical Principles. Copenhagen: Rhodos International Science and Art Publishers and Centre for Ethics and Law; 2000:61-74 at p. 74 .

12. Schiboleth nowadays stands for a code word for recognition. It is derived from Hebrew and goes back to the Old Testament, Book of Judges, Chapter 12, Verse 5ff, where it says: "And when refugees from Ephraim (came and) said: I would like to cross!, the men from Gilead asked: 'Are you an ephraimite?' And when one said no, they asked him: Please say 'shibboleth' and if he said 'sibboleth,' because he could not pronounce it, they took him and killed him near the river Jordan" (my translation).

13. Schopenhauer A. Preisschrift über das Fundament der Moral. Hamburg: Felix Meiner Verlag; 1977:64f [165-7].

14. Häyry M. Another look at dignity. Cambridge Quarterly of Healthcare Ethics 2004: 13:7-14 at pp. 11f. 


\section{Dissecting Bioethics}

15. Kant I. Groundwork of the Metaphysics of Morals. Cambridge: Cambridge University Press; 1997:5 (4:392).

16. See note 15, Kant 1997:7 (4:393-my emphasis).

17. See note 15, Kant 1997:42 (4:435); Hill TE Jr. Dignity and Practical Reason in Kant's Moral Theory. Ithaca: Cornell University Press; 1992:202-3.

18. Kant I. Metaphysische Anfangsgründe der Tugendlehre. Hamburg: Felix Meiner Verlag; 1990:74 (435).

19. Wood A. Kant's Ethical Thought. Cambridge: Cambridge University Press; 1999:115.

20. Höffe O. Medizin ohne Ethik? Frankfurt: Edition Suhrkamp; 2002:67.

21. Hill TE Jr. Must respect be earned? In: Peterson GB, ed. Tanner Lectures on Human Values 18. Salt Lake City: University of Utah Press; 1997:37-76.

22. See note 18, Kant 1990:110 (463) (my translation).

23. See note 18, Kant 1990:74f (435f) (my translation).

24. See note 15, Kant 1997:38 (4:429).

25. See note 19, Kant 1999.

26. According to Kant, dignity is based on rationality and hence restricted to those with rational capacities. It is beyond the scope of this paper to discuss the implications of this view for those whose rational capacities are diminished or nonexistent.

27. Lebech M. What is human dignity? In: Lebech M, ed. Maynooth Philosophical Papers NUIM: 2004;2:59-69 at p. 59.

28. Beyleveld D, Brownsword R. Human Dignity in Bioethics and Biolaw. Oxford: Oxford University Press; 2001:58.

29. Sensen O. Kants Begriff der Menschenwürde. In: Bormann FJ, Schröer C, eds. $A b$ wägende Vernunft. Berlin: de Gruyter; 2004: 220-236 at p. 221.

30. Dostojewski F. Schuld und Sühne. München: Piper; 1984:294f; my translation from German.

31. Coe J. The House of Sleep. London: Penguin Viking Books; 1997:312.

32. Aristotle. Wikiquote at: http://en.wikiquote. org/wiki/Nicomachean_Ethics\#Nicomachean_ Ethics_.28c._325_BC.29 (accessed Aug 24, 2007).

33. It is beyond the scope of this paper to defend the above claim. For a slightly longer exposition of the claim, see Schroeder D. A child's life or a "little bit of torture": Statesanctioned violence and dignity. Cambridge Quarterly of Health Care Ethics 2006:15(2)188201 , to be followed by a book in 2008. Aristotle argues for the unity of the virtues, which is necessary to sustain the claim in the following: Aristotle. Nikomachische Ethik. Hamburg: Felix Meiner Verlag; 1985:148-9 (1144b).

34. See note 33, Aristotle 1985:33-4 (1105b1106a); Solomon RC. On Ethics and Living Well. Belmont, CA: Thomson Wadsworth; 2006:91; Foot P. Virtues and vices. In: Virtues and Vices and Other Essays in Moral Philosophy. Oxford: Blackwell; 1978:1-18 at pp. 2-3; Hursthouse R. On Virtue Ethics. Oxford: Oxford University Press; 1999:167.

35. For a slightly longer exposition of this claim, see note 33 , Schroeder D.

36. Manifesto. The World Federation of Right to Die Societies, at: http://www.worldrtd.net/ members (accessed Aug 30, 2007).

37. See note 36, Manifesto.

38. Due to limits of space, I shall not discuss the relationship between dignity and advanced mental illness or permanent vegetative states as additional scenario.

39. Due to limits of space, I shall not discuss the possible criticism that a peaceful or dignified death is always impossible.

40. Diane Pretty dies. BBC News. May 12, 2002 at: http://news.bbc.co.uk2hi/health/ 1983457.stm (accessed Aug 30, 2007).

41. King CI. Death without Dignity in D.C. Jail. Washington Post 1995 Jul 15 at: http:// www.washingtonpost.com/wp-dyn/content/ article/2006/11/27/AR2006112700420.html (accessed Aug 30, 2007).

42. Allmark PJ. Death with dignity. Journal of Medical Ethics 2002:28:255-7 at p. 256.

43. Palliative care supporters will rightfully maintain that the prison and the hospital case should never have happened and that such situations can be avoided without resorting to physician-assisted suicide. I have chosen these extreme examples for emphasis as the fear of pain and embarrassment in death is real even outside extremes.

44. Dworkin R, Nagel T, Nozick R, Rawls J, Scanlon T, Jarvis Thomson J. Assisted suicide: The philosophers' brief. New York Times Book Review 1997;44(5) at: http://www.nybooks.com/ articles/1237 (accessed Sep 3, 2007).

45. See note 28, Beyleveld, Brownsword 2001:63

46. "Every day morality" is a term used by Dieter Birnbacher as opposed to ethical theory. "Lay morality" or "common sense morality" may be regarded as equivalent. Birnbacher D. Menschenwürde-abwägbar oder unabwägbar. In: Kettner M, ed. Biomedizin und Menschenwürde. Frankfurt: Edition Suhrkamp; 2004:249-71. 


\section{University Library}

\section{- M M I E E R VA A gateway to Melbourne's research publications}

Minerva Access is the Institutional Repository of The University of Melbourne

Author/s:

Schroeder, D

Title:

Dignity: two riddles and four concepts.

Date:

2008

Citation:

Schroeder, D. (2008). Dignity: two riddles and four concepts.. Camb Q Healthc Ethics, 17 (2), pp.230-238. https://doi.org/10.1017/S0963180108080262.

Persistent Link:

http://hdl.handle.net/11343/28265 